\title{
AZ AMERIKAI EGYESÜLT ÁLLAMOK TRÖSZTELLENES SZABÁLYOZÁSA - A SHERMAN ACT-TŐL A CELLER-KEFAUVER ACT-IG
}

A szerzố tanulmányában az Amerikai Egyesült Államok antitröszt-szabályozásának fejlôdését vizsgálja. Bemutatja, hogy melyek voltak a nyugati világ elsố modern antitröszt törvénye megalkotása mögött meghúzódó társadalmi, közgazdasági és politikai motivációk, illetve, hogy az idók folyamán ezek az igények miképpen formálták a szabályozás fejlődését. Az 1890-es Sherman Act elfogadásához vezetố legfóbb gazdasági probléma a monopoleró megjelenése és megerősödése volt; ezt az amerikai polgárháború utáni gyors ipari és technológiai fejlődés indukálta, beleértve a méretgazdaságossági elốnyök kihasználása elốtt álló korlátok lebomlásának lehetôségét is. A Sherman Act jelenti azóta is a szabályozás alapját, de nem a gerincét. A törvény által hagyott számos joghézag jó részét az 1914-es Clayton Act, és a szintén az adott évben elfogadott Federal Trade Commission Act szüntette meg. Az 1936-ban elfogadott Robinson-Patman Act természetét tekintve inkább volt intervencionista, mintsem liberális, míg a Celler-Kefauver Act tovább erôsítette az antitröszt és fúziókontroll közötti - az Egyesült Államokban egyébként sem gyenge - kapcsolatot."

Kulcsszavak: trösztellenes szabályozás, Amerikai Egyesült Államok, monopolerố

A XX. század fordulóján a világgazdasági erôtérben jelentôs változások következtek be. A gyarmatokkal rendelkezô nyugat-európai országok esetében kétségkívül azok gazdasági hatalmának csúcsáról beszélhetünk, míg a többi európai nemzet ezen a téren kihívni kívánta ezeket az államokat. Ez a rivalizálás azonban - a világháború következtében - a kontinens meggyengülését eredményezte. Mindeközben az Egyesült Államok korábban soha nem tapasztalt gazdasági fejlődésen és növekedésen ment keresztül. Mindez egyúttal azt is jelentette, hogy a XX. századra a kapitalizmus fejlődésének motorja számos tekintetben áttevődött a tengerentúlra, s ezzel karöltve, bizonyos, a kapitalizmus jelentette kihívásokra is először az USA-ban kerestek válaszokat. Így jellemezhetô a gazdaságszabályozás keretében megvalósuló modern antitröszt-szabályozás is, amelynek elsố jelentős állomása az 1890-ben elfogadott Sherman Act volt.

A XIX. század végén kezdôdô amerikai trösztellenes szabályozás a monopolerô, pontosabban az ahhoz kapcsolódóan (potenciálisan) felmerülő gazdasági kihívásokra keresett választ. A szabályozás ekkor még egyáltalán nem volt kiforrott; a sok joghézag ugyanakkor mindenkor serkentett a szabályozás tökéletesítésére és kiteljesítésére. Ez utóbbi két jelleg természetesen csak feltételesen értelmezhetô, abszolút állapotról nem beszélhetünk. Az antitröszt-szabályozási folyamatot tehát fóleg a problémákra keresett utólagos válaszok sorozataként értelmezhetjük, és ily módon annak ,tökéletessége" nagymértékben függött a gazdasági folyamatok, a piaci változások sebességétól, illetve attól, hogy a közgazdaságtudomány mennyire tudta ezeket helyesen definiálni. Tanulmányunkban az amerikai antitrösztszabályozás fejlódését tekintjük át oly módon, hogy a fejlődést a mindenkor felmerülő piacmúködési zavarokra adott válaszként értelmezzük, de magukat a piacmúködési zavarokat nem tárgyaljuk. Ezek klasszikusan a mikroökonómia és a modern piacelmélet (Industrial Organisation - IO) kutatási területei közé sorolhatók. 
Az elsô fejezetben a korabeli angolszász gondolkodás néhány, a monopolerôvel foglalkozó tételét említjük meg. Adam Smith munkássága ebból a szempontból is kiemelkedô, hiszen az antitröszt területén ma is helytálló összefüggéseket írt le. A második fejezetben a XIX. század második felére jellemzố egyesült államokbeli gazdasági-társadalmi viszonyokat mutatjuk be, de csak olyan szinten, hogy a késóbbiekben bemutatásra kerülő szabályozást megfelelő értelmezési kontextusba tudjuk helyezni. A tanulmány harmadik nagy egysége az amerikai trösztellenes szabályozás fejlôdését írja le. A szabályozás fejlődése - évtizedes idôtávokban gondolkozva - mindazonáltal a fúziókontroll felé történő „nyitással” is jellemezhetô, így témánk taglalása nem lenne teljes a két versenyszabályozási ág metszetét jellemző legfóbb eredmények ismertetése nélkül. A tanulmány zárásaként röviden jellemezzük a corporate governance vívmányait, meglátásunk szerint ugyanis ezen elvek követése nélkül a trösztellenes szabályozás nem tudná elérni a hozzá fúzött célkitűzéseket, beleértve az egyik legfontosabbat is: az etikus üzleti magatartás gyakorlását.

\section{Gondolatok a korabeli angolszász trösztellenes felfogásról}

A kapitalista világrend mai arculatának kialakulását jórészt a nyugati társadalmak gazdaság- és társadalomfejlődése határozta és határozza meg. A fejlődés, ami természetesen nem volt tudatos és egyenes vonalú folyamat, először Nyugat-Európában indult meg. Ennek első jelentősebb, klasszikusnak mondható szellemi manifesztálódása Adam Smith, David Ricardo és más korabeli gondolkodók nevéhez köthetô, ${ }^{1}$ de a közgazdaságtan fejlődése ekkor még nem feltétlenül választható el élesen a többi tudománytól, hiszen ennek intézményesített formája késóbb alakult ki. Az ipari forradalom szerepe ezekben a folyamatokban mindenesetre nem tagadható, és ez olvasható ki a korabeli közgazdasági eszmék kialakulásának földrajzi vetületéból is. Ebben az időben még nem beszélhetünk a mai értelemben vett, a mai tartalommal rendelkező trösztellenes szabályozásról sem, ennek alapjai esetenként a közgazdaság más területein gyökereznek. Témánk szempontjából ezek közül kiemelendô a kereskedelempolitika, amelynek mentén Smith és Ricardo is megalkotta híres elméletét, és az iparpolitika. Mindezen eszmei fejlódés mellett, és azokat indukálva, a nyugati társadalmak - az eredeti tókefelhalmozás révén - megvetették a ma is múködő kapitalista piacgazdaság alapjait. A tóke, mint termelési tényező, előtérbe kerülése (a munka, de elsôsorban a föld kárára) azonban egy új, addig esetlegesen csak más formában ismert helyzetet eredményezett: a tókés gazdasági hatalmat. A tókés hatalom jellege jelentôsen különbözött a földesúri hatalomtól, amely jellemzői közül, tanulmányunk szempontjából legalábbis, elsősorban a tốke mobilitása, a termelés relatív állandósága és annak relatív magas volumene emelendó ki. A technológiai és infrastrukturális fejlődés ugyanis lehetővé tette a termelési hullámvölgyek kisimítását és a nagyobb földrajzi távolságok leküzdését (Waldman - Jensen, 2001). Ez egyrészt további ösztönzóként is hatott a fejlődésre, a pénztóke mint eszköz megjelenése és megerôsödése azonban csakhamar új problémákat is eredményezett. Ilyen például a monopoleróvel való visszaélés kérdése vagy a piac állami szabályozásának és ellenőrzésének mértéke, amelyek kapcsán a válasz esetenként csak évtizedekkel késóbb született meg. Az állam korai piacszabályozási gyakorlata tehát inkább reaktív, semmint proaktív, ez a jegy a kapitalista gazdasági rendról jobbára azóta is elmondható.

A monopólium problémakörével mindazonáltal már Adam Smith is foglalkozott. Legismertebb múvében, A nemzetek gazdagsága (1776) címú könyvében párhuzamba állítja a monopolerót és a tökéletes versenyt, kiemelve ezek legfóbb - ma is helytálló - jellemzóit. A monopóliumokkal kapcsolatos véleményét úgy fogalmazza meg, hogy mivel az ,állandó áruhiányt idéz eló azzal, hogy sohasem elégíti ki a tényleges keresletet, a monopolista áruját jóval a természetes ár felett adja el, s így a jövedelmét, legyen az munkabér vagy profit, jelentôsen a természetes ráta szerinti szint fölé emeli" (Smith, 1959: 110. o.). Smith párhuzamba állítja elóbbit a szabad versennyel, és rámutat, hogy a tiszta verseny hosszú távon alacsonyabb árakat eredményez.

Smith versenypiac melletti elkötelezettsége tehát egyértelmú, de múve arra is választ ad, hogy hogyan vélekedik az államnak a piactorzító tevékenységekkel kapcsolatos feladatairól. Ezt két síkon lehet értelmezni, amit aktív és passzív magatartásként értelmezhetünk. Elóbbi, azaz az állam által aktívan kifejtett tevékenység vonatkozásában jogalkotást és kikényszerítést vár el az államtól, és ennek fényében fogalmazza meg elvárásait is az állami szabályozással szemben. Smith szerint a „szakmabeli összejövetelek ... majdnem mindig azzal végződnek, hogy a résztvevốk mintegy összeesküsznek a közönség érdekei ellen, valamiféle áremeléseket gondolnak ki. ... De ha már nem tudja meggátolni, hogy az egy szakmához tartozók néhanapján összejöjjenek, legalább azt ne tenné meg a törvény, hogy megkönnyíti, sôt egyenesen szükségessé teszi összejöveteleiket" (Smith, 1959: 179. o.). Smith másik elvárását az államtól a monopolhelyzetek „kezelése” kapcsán az állami beavatkozás módja elleni kritikaként is felfoghatjuk. 
Szerinte ugyanis az állam megerósíti a polgárok kollúziós aktivitását azáltal, hogy bizonyos adminisztratív elôírásokat kötelezôvé tesz.

Általánosságban a szabadság témakörével a korabeli angol gondolkodók közül John Locke is foglalkozott, aki szerint ,mindenkinek joga van ahhoz, hogy a boldogságot keresse és meghatározza érdekeit" (Neumann, 2001: 3. o.). Locke-hoz hasonlóan John Stuart Mill sem csak a piaci szabadságról értekezik, jóllehet úgy a tág értelemben vett, mint a piaci szabadságot kívánatosnak tartja. A XVIII. század nagy angol gondolkodója a Szabadságról (1859) címú múvében a kérdéskörról így ír: „ma azonban - igaz, hosszú küzdelem eredményeként - azt tartják, hogy a javak olcsóságát is, jobb minőségét is az biztosítja a leghatékonyabban, ha tökéletes szabadságot adnak termelónek is, eladónak is, melyet csupán az korlátoz, hogy a vásárlónak ugyancsak teljes szabadságában áll másutt beszerezni a kívánt javakat. Ez a szabad kereskedelem tana..." (Mill, 1983: 199. o.).

Smith és Mill monopóliumokkal kapcsolatos álláspontjából kitűnik, hogy már a korabeli piaci viszonyok közepette sem tartották kívánatosnak a piac túlságos polarizálódását. A tudományterület szigetországi elméleti fejlődését, amelyet természetesen nem merítettünk ki a két gondolkodó releváns meglátásainak rövid bemutatásával, nem választhatjuk el a tengerentúli jogfejlődéstôl sem, meglátásunk szerint a kettő között ok-okozati összefüggés van, amely folyamat indikátorai többek között az esetjog amerikai alkalmazásában, a közös történelmi múltban, vagy a betelepülók etnikai összetételében is kereshetôk. Saját korában az újonnan elfogadott Sherman Act mindazonáltal messze túlmutatott az Egyesült Királyság (és egész Európa) trösztellenes gyakorlatán, így a következókben a Sherman Act elfogadásához vezetô fốbb amerikai társadalmi és gazdasági fejleményeket tekintjük át, annak érdekében, hogy a Sherman Act rendelkezéseit (és késóbbi módosításait) helyesen tudjuk értelmezni.

\section{Út az amerikai antitröszt-szabályozás megteremtése felé}

A modern állam, mint a piaci szabályozást megvalósító, a piactól - a liberális felfogás szerint - független szervezet, mindig is hozott piacszabályozó intézkedéseket, mégpedig közvetlen vagy közvetett módon. Az ilyen állami intervenció úgy az Óvilágban, mint az Újvilágban megjelent, de az idóben, a beavatkozás módjában és a beavatkozás mélységében igencsak eltérő jellegeket figyelhetünk meg. Németországban például az állam első, kartellekkel kapcsolatos ,állásfoglalása” indirektnek tekinthető, hiszen egy 1897-es bírósági ítélet azt mondta ki, hogy „a kartellszerződések nem korlátozzák más szereplő́k szabadságát” (Pelle, 2010: 93. o.), s így a kartellek létezését ez az ítélet egyenesen igazolta (Neumann, 2001). Az Egyesült Államokban, a helyi piacon végbemenó folyamatokra válaszul, 1890-ben fogadták el az elsố trösztellenes törvényt, amely elôterjesztője John Sherman - után a Sherman Act nevet kapta.

„Ha egy olyan világban élnénk, amely a tökéletes verseny paradigmája szerint múködne, kevés szükség lenne antitröszt-szabályozásra és egyéb szabályozó tevékenységre" - érvel egy statikus modellben a Viscusi - Vernon - Harrington, Jr. (2000: p. 2.) szerzői hármas, de rögtön el is ismerik, hogy a teljesen tökéletes verseny elmélete igencsak elrugaszkodik a valóságtól. A Waldman - Jensen (2001) szerzópáros tulajdonképpen ezt az alapállapotot dinamizálja, hiszen rámutatnak, hogy a Sherman Act elfogadásához több olyan tényezó is hozzájárult, amelyek egyértelmúen a gazdasági-társadalmi környezet változásának tudhatóak be. A szerzók a következő négy jelenséget emelik ki: a) a tömegtermelés megjelenését és elterjedését, általánosan fogalmazva: a méretgazdaságosság kiteljesedésének lehetôségét, b) a vasúthálózat fejlődését, amelynek köszönhetően a nagy távolságok is leküzdhetókké váltak, c) a tôkepiacok fejlődését, amely hozzájárult a minden korábbinál nagyobb vállalatok létrejöttéhez, és d) a fúziós jogszabályok elterjedését (a szövetségi államok szintjén).

Az amerikai polgárháború (1861-1865) utáni idôk jelentôs gazdaságpolitikai-piacszabályozási kérdéseket vetettek fel. Higgs (2011) a korabeli (1865 utáni) acélipari termelésfelfutásra hívja fel a figyelmet, rámutat, hogy ,az acél iránti kereslet oly gyorsan növekedett, hogy a vállalkozói haszon magas maradt, ami sok acéltermelő́t ... milliomossá tett" (3. o.). Nem jellemezte hasonló mértékú felfutás az összes iparágat, viszont az acélipar mellett - az olajipar koncentrációja is felvetett versenyjogi kérdéseket. ${ }^{2}$ Az olajipar kapcsán a Standard Oil vállalat esete jelentős versenyjogi ítéletet hozott a századfordulón, de erról majd késóbb, a jogértelmezés kapcsán ejtünk szót.

Higgs (2011) a XIX. sz. második felére jellemzó amerikai piaci környezet vizsgálata kapcsán tett legfőbb megállapítása az, hogy ,,a polgárháború utáni amerikai gazdaság nem volt tökéletesen versenyző" (9. o.), viszont nem volt kirívó a verseny korlátozása. Országos szinten azonban csak a - méretgazdaságossági értelemben - kellóen nagy vállalatok voltak képesek domináns pozíció kialakítására. Viscusi - Vernon - Harrington, Jr. (2000) explicite is kimondja, hogy ,az 1890-es Sherman Act volt a politikai reakció az 1880-as években létrejövő, nagyméretú ,"üzleti kombinációk”, vagy trösztök terjedésére" (65. o.). A Legfelsốbb Bíróság a 
Brown Shoe Company vs United States (1962) hozott ítéletében pedig kiemeli, hogy ,a verseny az, és nem a versenytársak, amit a Törvény véd" (Justitia, 2013: 370. o.). A korabeli amerikai gondolkodásmód teljes képéhez azonban az is hozzátartozik, hogy voltak, akik üdvözölték (de legalábbis megtứrték) a kartellek múködését. John Bates Clark egy 1887-es múvében kiemeli, hogy ,az összeállás gyökerei a társadalmi felfogású iparba (,,social industry” - a szerző) nyúlnak vissza, és eredetüket, fejlődésüket és gyakorlati múködésüket tekintve normális képződményeknek tekintendôek. Nem kell óket sem a tudósoknak elítélni, sem pedig a jogalkotóknak elnyomni" (Neumann, 2001: 25).

Az 1880-as évekre tehát az ipari-technológiai fejlődés és a méretgazdaságosság felfutásának következtében egyre nagyobb problémává vált a monopóliumok kezelése, amely egyúttal jelentôs gazdaságszociológiai kérdéseket is felvetett. Neumann (2001) megállapítása jól szemlélteti a gazdaság társadalmi ,alávetettségét”, amikor kimondja, hogy ,,a Sherman Act-et egy olyan évtized után hívták életre, amelyet társadalmi nyugtalanság, sztrájkok és anarchista izgatottság jellemzett" (32. o.). A következókben e kihívás orvoslására megalkotott Sherman Act-ot mutatjuk be és elemezzük.

\section{A Sherman Act-tól a Celler-Kefauver Act-ig}

Az állam piaci beavatkozásával kapcsolatban a szabályozás két síkon is megvalósulhat: egyrészt a trösztellenes szabályok megalkotásával (és betartatásával), másrészt pedig a közvetlen szabályok (direct regulation) meghozatala révén (Viscusi - Vernon - Harrington, Jr., 2000; Waldman - Jensen, 2001). A közvetlen szabályozás kapcsán Waldman - Jensen (2001) rámutat arra, hogy az az 1880-as évek végétől figyelhető meg, jóllehet az első állami szabályozói tanácsot (state regulatory board) már 1874-ben életre hívták, a közszolgáltatási bizottságok (public utility commissions) pedig jelentős hatalommal rendelkeztek a piaci folyamatok irányításában (Waldman - Jensen, 2001). A közvetlen szabályozásra mindazonáltal jelentős befolyással lehet a mindenkor aktuális politikai irányítás, eszmei felfogás és a technikai haladás. Ezzel továbbá párhuzamba állítható a terjedő dereguláció (Waldman - Jensen, 2001) és a liberalizáció ${ }^{3}$ is, ami a piaci folyamatok (zavartalan) érvényesülése előtt álló akadályok lebontásában nyilvánul meg.

A másik törvénykezési „séma”: a klasszikus értelembe vett piacszabályozás lényegesen eltér a közvetlen szabályozástól. A trösztellenes szabályok korokon átívelő, általános gazdasági problémára kívánnak választ adni. Ez a kettős jelleg megfigyelhető a Sherman Act kapcsán is, hiszen egyrészt az - a módosítások mel- lett - 1890 óta hatályos, másrészt olyan általános - a szabad verseny szempontjából - „torzulásra” kíván(t) választ adni, mint amilyen a monopolerôvel történő visszaélés. Az immár tradicionálisnak mondható amerikai antitröszt-szabályozás így szoros kapcsolatot mutat a fúziókontrollal. Az amerikai trösztellenes szabályozás tárgyalásakor ezért nem tekinthetünk el a vállalati koncentráció kérdéskörének érintốleges vizsgálatától sem. ${ }^{4}$

Az Egyesült Államok trösztellenes szabályozásának alapját a Sherman Act jelenti. A törvény tervezetét John Sherman (1823-1900), ohioi republikánus szenátor előterjesztésére az amerikai szenátus 1890. IV. 8-án 51-1 szavazati arányban fogadta el, amit 1890. VI. 20-án a Felsôház 242-0 arányban meg is erősített. Benjamin Harrison elnök 1890. VII. 2-án írta alá, és az ezáltal jogeróre emelkedhetett (Ourdocuments, 2013; Congress, 2013). A Sherman Act 1. cikke általános tiltást fogalmaz meg a kollúzív magatartások kapcsán, amikor így fogalmaz:

„Minden szerzódés, öltsön az tröszti, vagy más szö-
vetkezési formát, illetve összeesküvés, amelynek
célja, hogy korlátozza a forgalmat vagy a kereske-
delmet az Államok között vagy más népekkel, ezál-
tal illegálisnak ítéltetik. Minden személy, aki ilyen
szerzódést köt, vagy ilyen jellegú összeesküvésben
vesz részt, vétséget követ el, és annak büntetéseként
ötezer dollárt meg nem haladó bírsággal, vagy egy
évnél nem hosszabb börtönbüntetéssel büntettetik
meg, vagy mindkét említett büntetéssel, a bíróság
mérlegelése alapján.” (Sherman Act, 1890: 1. cikk)

A Sherman Act legfontosabb rendelkezése tiltja a horizontális és vertikális korlátozásokat is, de monopolhelyzetbe kerülni nem tilos. Az 1. cikk központi eleme a kereskedelem korlátozásának tilalma, jóllehet a szabályt megszegó elleni büntetóeljárás lehetôségét is magában hordozza. Ez utóbbi, tehát a megállapodásban részes fél büntetôjogi felelôsségre vonhatósága sajátossága nemcsak az amerikai, de ma már az angolszász jogi gondolkodásnak is, hiszen több országban is (például az Egyesült Királyságban és Írországban) így kívánják „nyomatékosítani” a kartellben való részvételért járó pénzbüntetést, illetve elrettenteni a kartelltevékenységtől (Sherman Act, 1890; Aubert, 2007). A bíróság szerepe azonban nemcsak a kikényszerítésben érhetô tetten, hanem a jogértelmezésben is. Kérdést vet fel ugyanis, hogy mit értettek a „megállapodás” fogalma alatt; Nagy (2010) rámutat arra, hogy ,az amerikai antitröszt jog, az európai versenyjoghoz hasonlóan, szintén rögös utat járt végig annak érdekében, hogy a „megállapodás” számára egy múködóképes meghatározást alkosson; sajnos, hasonló sikertelenséggel" (15. o.). 
Amint arra a fentiekben is utaltunk, az amerikai trösztellenes szabályozás szoros kapcsolatot mutat az összefonódás-ellenőrzéssel, amelynek gyökerei fellelhetốk a Sherman Act-ben. A jogalkotó közgazdasági tudatosságáról tesz tanúbizonyságot, hogy nem pusztán a kollúziót, de az ebból potenciálisan ,adódó” monopolhelyzetet is bevonta a szabályozásba. A Sherman Act 2. cikke, amit az amerikai szakirodalom csak ,,Section 2"-nak nevez (Viscusi - Vernon - Harrington, Jr., 2000; Adkinson - Grimm - Bryan, 2008; Klotz, 2008), a monopolizálás törvénytelen jellegét mondja ki.

Mindazonáltal, a Sherman Act-nek talán éppen a monopolhelyzetek kezelése a legkevésbé kiforrott területe, és ez visszaköszön a bírói joggyakorlatban is. Neumann (2001) rámutat arra, hogy az amerikai bíróságok - eltérve az angol gyakorlattól - mindenféle versenykorlátozó magatartást tiltanak, s ez az általános tiltás vezetett el a Sherman Act viszonylag korai újragondolásához is, hiszen nem tudta megfelelően kezelni a monopolerôvel történő visszaélést. 1898-ban ugyanis a fellebbviteli bíróság a US vs Addyston Pipe and Steel Company ügyben hozott ítélettel általános, azaz per se jelleggel törvényellenesnek minôsített minden horizontális megállapodást, és ez egyenesen vezetett a XIX-XX. század fordulóján minden addiginál erősebb fúziós aktivitáshoz (Neumann, 2001). A szerzố szerint a Standard Oil Company (1882) volt az elsố tröszt az Egyesült Államokban, de a trösztösödés ütemét szemléltetendő, a Nevins - Commager szerzôpáros alapján megjegyzi, hogy „1904-ben 319 ipari tröszt létezett, amelyek 5300, korábban független vállalatot öleltek fel" (Neumann, 2001: 6. o.).

A Sherman Act körüli jogértelmezési bizonytalanságnak nemcsak a per se felfogás „segítségül hívása” volt a jellegzetessége, hanem a rule of reason elvének kialakítása is. A Legfelsóbb Bíróság ugyanis az 1911ben a Standard Oil Company magatartása kapcsán hozott ítéletében kimondta, hogy „sem a nagyság, sem a monopoleró birtoklása önmagában nem vétség. A Sherman Act a monopolizálási szándék és cél ellen irányul, mint olyan magatartás ellen, amely túllép az ipari fejlődés normális módszerein" (Neumann, 2001: 35. o.).

A Sherman Act által nyitva hagyott kérdések orvoslására, illetve a fúziós hullám kihívásaira a trösztellenes szabályozás válasza 1914-ben érkezett. A Clayton Act és a Szövetségi Kereskedelmi Bizottságról szóló törvény ${ }^{5}$ (Federal Trade Commission Act - FTC) elfogadásával a Sherman Act által hagyott joghézagokat kívánták megszüntetni, növelve a jogbiztonságot és a piaci szabadság védelmét. Fiorito (2011) megállapítja, hogy „az 1914-es Clayton Act sorolta fel elsőként azokat a tilos magatartási gyakorlatokat, amelyek valószínúsíthe- tő hatásai »a verseny jelentôs csökkenését és monopólium felé történô elmozdulást « hordoznak magukban" (3. o.). A törvény értelmében jogellenesnek minősült az árdiszkrimináció, az árukapcsolás és a kizárólagos forgalmazás, a versenytárs vállalkozás bekebelezése és a vállalati igazgatóságok összekapcsolása (Neumann, 2001; Fiorito, 2011; DoJ, 2012). Neumann (2001) kiemeli továbbá, hogy míg ,a Sherman Act a monopoleró káros hatásait kívánta elhárítani, és ...karakterét tekintve defenzív volt, a Clayton Act pozitív lökést adott az USA antitröszt szabályozásának" (34. o.). A szerző ezt két olyan tényezôvel is alátámasztja, amit a Clayton Act honosított meg. Egyrészt, míg a Sherman Act alapján utólagosan kellett bizonyítani a trösztellenes szabályok megszegését (azaz: igazolni kellett a visszaélés gyanúját), addig a Clayton Act magát a tiltást olyan formában írta eló, hogy nem volt engedélyezett a piacon meghatározott magatartást tanúsítani. Ugyanakkor a jelentéktelen versenykorlátozások kikerültek az általános tiltás hatálya alól, és ezt később a bíróság meg is erősítette.

Viscusi - Vernon - Harrington, Jr. (2000) rámutat, hogy az amerikai antitröszt-szabályozás gerincét a Sherman Act - Clayton Act - Federal Trade Commission Act képezi, és ennek középpontjában legalábbis közgazdaságilag - a gazdasági hatékonyság védelme és növelése áll. Az 1929-33-as válság azonban felülírta ezeket a megfontolásokat, hiszen az állam piacszabályozó tevékenysége a válság alatt reaktívnak tekinthetô olyan értelemben, hogy az inkább a kialakult gazdasági helyzetre, semmint egy konkrét magatartásra kívánt választ adni. Az Amacher - Ulbrich (1986) szerzópáros rámutat, hogy habár a Roosevelt-adminisztráció mandátuma elején nem foglalkozott különösképpen a trösztösödés szabályozásával, a National Recovery Administration (NRA) elfogadásával a versenyszabályokat gazdaságösztönzô célokra használták fel; rámutatnak, hogy ,az NRA versenyellenes volt, mivel engedélyezte és ösztönözte a vállalatok közötti megállapodásokat" (335. o.). Ginsburg (2009) a New Deal kapcsán ugyanakkor megjegyzi, hogy az USAban a modern szabályozás a program elfogadásához kötődik, hiszen előtte ,,a kereskedelmet pusztán gazdasági alapokon »szabályozták «, majdnem kizárólag csak antitrösztszabályok révén" (Ginsburg, 2009: 1. o.). A szerző a New Deal előtti és utáni kor legfő́bb különbségét abban látja, hogy ,a New Deal, amely inkább a szabályozásra, semmint a versenyre és az iparspecifikus jellegekre helyezi a hangsúlyt, radikális szakítás volt az ortodox antitröszt politikával" (1. o.). Szerinte az új antitrösztfelfogás középpontjában a korporációs állami szabályozás állt, melynek célja, hogy a verseny korlátozása révén megteremthetô termelői többletet végül is 
a gazdaságba visszajuttatva (bérek és beruházások révén), kimozdítsák a gazdaságot a holtpontról. Ugyanakkor azt is leszögezi, hogy a Legfelsóbb Bíróság az A.L.A. Schecter Poultry Corp. vs United States (1935) ügyben alkotmányellenesnek minôsítette a szabályozás ezen módját.

Természetesen az Egyesült Államok antitrösztszabályrendszerét is többször módosították, de a változtatások - a Sherman Act - Clayton Act - Federal Trade Commission Act - hármas megalkotásának volumenéhez nem mérhetốk. A trösztellenes regulákban hozott következó jelentôs változásra 1936-ig kellett várni, amikor is elfogadták a Robinson-Patman Act-ot a termelőipari kiskereskedók védelmére (Neumann, 2001). A szerzố úgy látja, hogy a törvény jelentôs állami beavatkozásnak tekinthetô, mivel ezáltal „az antitrösztpolitikát fellazították, és intervencionista iparpolitikával váltották fel" (36. o.) - az egyik motiváció ugyanis a nagykereskedók erejének megtörése volt. A Robinson-Patman Act az árdiszkrimináció három fajtáját per se törvényellenesnek minősítette. Ezek az adott ügylet igazolhatóságával, az alkuszdíjjal és a fizetésbeli diszkriminációval kapcsolatos tiltásokat fogalmazták meg (Waldman - Jensen, 2001). A szerzók ugyanakkor arra is rámutatnak, hogy a törvény „rendkívül ellentmondásos, mivel azt gyakran a versenytársaknak és nem magának a versenyfolyamatnak a védelmére használták" (560. o.). A törvényt késốbb fó változtatás értelmében annak hatálya kiterjedt a vertikális és konglomerátum jellegú összefonódásokra is (Waldman - Jensen, 2001). A szabályozás hatása ezen messze túlmutat, hiszen a szerzók kiemelik, hogy - a Celler-Kefauver Act alapján - a Brown Shoe Company vs United States ügyben hozott ítélet precedensként szolgált, ami adott esetben rányomhatta bélyegét a késốbbi jogértelmezési trendekre is. Leszögezik: a precedens ,,azt sugallja, hogy a horizontális fúziókat még a versenyzố piacokon is tiltani kellene, megelôzendố a jövốbeli koncentráció növekedését" (Waldman - Jensen, 2001: 592. o.). A törvény elfogadása után a horizontális fúziók száma visszaesett (Audretsch, 1985). Ezek után (és révén) ismét az a szabályozói felfogás nyert teret, melynek eszmei fó iránya szerint ,a verseny a legjobb piacszabályozó" (Ginsburg, 2009: 2. o.).

A vállalati összefonódások ellenőrzését azonban nemcsak a Celler-Kefauver Act szolgálja. 1968-tól kezdődően az Igazságügyi Minisztérium iránymutatásokat ad ki az összefonódásokkal kapcsolatban. Az iránymutatások közös jellemzője, hogy azok nemcsak a horizontális, hanem a vertikális és konglomerátum összefonódásokat is szabályozzák. Az 1982-es iránymutatás már a Herfindahl-Hirschmann Index (HHI) alapján értékeli az összefonódásokat, és nem az inputvagy outputrészesedés alapján (Waldman - Jensen, 2001). A horizontális összefonódások jelentette potenciálisan versenykorlátozó magatartások megállapítása

\section{A Herfindahl-Hirschmann Index és az összefonódás-ellenôrzés hatásvizsgálata az Egyesült Államok horizontális trösztellenes értékelésében}

\begin{tabular}{|c|c|c|}
\hline Fúzió utáni HHI-érték & A fúzió jelentette HHI-érték változása & Összefonódás-ellenőrzés hatásvizsgálata \\
\hline $1000-1800$ & $0<\mathrm{HHI}<100$ & nem valószínú \\
\hline $1000-1800$ & $100<\mathrm{HHI}$ & valószínú \\
\hline$>1800$ & $100<\mathrm{HHI}$ & nagyon valószínú \\
\hline$>1800$ & $0<\mathrm{HHI}<100$ & valószínú \\
\hline$>1800$ & $0<\mathrm{HHI}<50$ & nem valószínú \\
\hline
\end{tabular}

Forrás: Waldman - Jensen, 2001 alapján saját szerkesztés

alkotmányellenesnek minósítették, és az 1950-es évektól ismételten visszatértek a szigorúbb versenyszabályozási elvekhez (Neumann, 2001).

Az amerikai antitröszt-szabályozás utolsó nagyobb kiegészítése az 1950-ben elfogadott Celler-Kefauver Act volt, amely egy fúziós joghézagot kívánt megszüntetni. A törvény egyrészt kimondta, hogy a Clayton Act vonatkozó (7.) cikke ${ }^{6}$ nemcsak a részvényszerzés útján történő összefonódásokra irányadó, hanem az eszközök megszerzésével végrehajtott fúziókra is. A másik érdekében, a HHI-re alapozva, értékelési sémát alakítottak ki, ennek sarokpontjait szemlélteti az 1. táblázat.

Az összefonódás-ellenôrzési iránymutatás jogszabályi formában a Hart-Scott-Rodino (HSR - 1976) Act révén testesült meg (IP, 2013). Ez a fúzió létrejötte előtt ír elő bejelentési kötelezettséget (premerger notification report - PNR), amiben a fuzionálni kívánó nagyvállalatok üzleti eredményeiról ${ }^{7}$ kell nyilatkozni a Clayton Act 7. cikke alapján. A vállalatok a bejelentést a Federal Trade Commission-nél és az Igazságügyi Minisztériumnál kötelesek megtenni, amely szervek a HSR Act-ben meghatározott határidốn belül döntenek 
a kérelemról (FTC 2013b). A Waldman - Jensen (2001) szerzópáros ugyanakkor rámutat arra, hogy az 1982-es iránymutatás a vertikális vagy konglomerátum-piaci összefonódás-értékeléskor nem a HHI alapján jár el. ${ }^{8}$

A Hart-Scott-Robinson Act megalkotásával a jogalkotó célja összességében az volt, hogy elejét vegye a potenciálisan versenyellenes összefonódásoknak (IP, 2013), mindezt pedig úgy kívánta megvalósítani, hogy az idốk folyamán az összefonódás-ellenôrzési irányvonal „,felhagyott az agresszív antifúziós politikai gyakorlattal" (Waldman - Jensen, 2001: 600. o.). A vállalati egyesülés ilyen jellegú ellenőrzése jelentős hasonlóságot mutat tehát az Egyesült Államok és az Európai Unió központi motívumai között.

A két jogrendszer közeledése felé mutat az a tendencia is, mely szerint az összefonódások potenciális hatásainak értékelésében egyre nagyobb szerepet kap azok gazdasági hatékonyságra gyakorolt hatásának vizsgálata. Waldman - Jensen (2001) szerint, amíg az 1982-es iránymutatás elveti ennek vizsgálatát, a két évvel késóbbi felülvizsgálat már elismeri a fontosságát, de nem mint kizárólagos tényezốt kezeli. A korábbi, az iparági koncentrációs fokra összpontosító szempontrendszer relevanciája pedig az 1992-es felülvizsgálattal tovább csökkent.

\section{Piacszabályozás a gyakorlatban: a corporate governance magatartási alapelvei}

Az 1929-1933-as gazdasági világválság, mely az Egyesült Államok gazdaságában okozta a legnagyobb visszaesést (Romer, 2003), több szempontból is új gazdaság(irányítás)i gyakorlatok és módozatok meghonosodását eredményezte. Mivel ez a válság minden korábbinál jelentôsebb megrázkódtatást jelentett az Egyesült Államok gazdasága számára, a reá adott válaszok is újszerúek voltak, ezeket azonban immár két síkon értelmezhetjük. Egyrészt az állami beavatkozás és szabályozás szintjén, ahogy jelen dolgozatnak is ez a központi témája. Másrészt a válság éveiben született meg a vállalatirányítási magatartást tudományosan vizsgáló irányzat (Berle - Means, 1991), melyet ma már a corporate governance fogalmával illetünk.

A corporate governance témakörében úttörönek tekinthetô Adolph Berle és Gardiner Means The Modern Corporation and Private Property címú 1932-es múve. Az Egyesült Államokban jelentkezô új trendet ez alapján úgy jellemezzük, mint amelyben a tốke tulajdonlása és az irányítás intézménye különválik (La Porta - Lopez-de-Silanes - Shleifer, 1999). Amacher és Ulbrich (1986) a fogalmat a ,separation of ownership and control” kifejezéssel írja le (279. o.). Eltekintve a szemantikai vizsgálódástól, érdemes megjegyezni, hogy a „control” kifejezés az ,irányítás” mellett „felügyelet"-et is jelent; ezzel is a corporate governanceszel kapcsolatos, a piaci szabályok betartására irányuló felelősségvállalásra kívánjuk felhívni a figyelmet. A corporate governance irodalma és spektruma tehát rendkívül széles, ezért jelen tanulmányban csak azokat az általános elveket vesszük górcsố alá, amelyek korunk döntéshozói, részvényesei és menedzserei számára iránymutatást jelenthetnek a vállalati magatartás gyakorlásában. Az idôsíkok ilyen jellegú közelítésével nem titkolt célunk felhívni a figyelmet a versenyszabályozás és a corporate governance közötti kölcsönhatásra.

A szabályozásnak a corporate governance-re gyakorolt hatását olyan értelemben vizsgálhatjuk, hogy az milyen módon befolyásolja a vállalatok magatartását. A vállalati magatartást nemcsak a versenyszabályok alakíthatják, hanem a jog különböző ágai is (pl. a társasági vagy a pénzügyjog). Érdemes megemlíteni, hogy a döntésekkel járó felelősség viselésének kérdése is kettős. Az Egyesült Államok trösztellenes törvényei kiválóan kidomborítják ezt a dichotómiát. A törvényszegésért felelôsségre vonható a vállalat mint gazdasági szereplő. Az ilyen peres eljárások végén születnek meg azok a (legfelsóbb) bírósági ítéletek, amelyek az Egyesült Államok trösztellenes esetjogának gerincét képezik. Az esetjogon kívül a trösztellenes szabályozás másik sarkalatos jellegzetessége a magánszemélyek perbe foghatósága, az ilyen jellegú kikényszerítés az Egyesült Államokból indult, de több angolszász ország büntetôjogában is fellelhetô (Aubert, 2007).

A felelős vállalatirányítás fontosságát nemcsak a nemzetállamok tartják szem előtt, jóllehet ók a jogosultak a piacok szabályozására (hacsak nem ruházták át szuverenitásuk egy részét nemzetközi szervezetekre, amint azt az Európai Unió esetében látjuk). Bainbridge (2012) egyenesen megkérdőjelezi, hogy a legmagasabb törvényhozási szinten valóban hatékonyan lehet-e szabályozni a vállalati viselkedést. Minden bizonnyal az ilyen jellegú diskurzusok is hozzájárultak ahhoz - a szakmai támogatás igénye mellett -, hogy az OECD 2004-ben felülvizsgálta a corporate governance-ról korábban kialakított iránymutatásait. Az OECD-alapelvek a corporate governance-ról címú kiadvány megszólítja a döntéshozók mellett a vállalatokat és a befektetóket is, felismerve ugyanis, hogy ,a mai gazdaságokban a corporate governance vizsgálódása túlmutat a részvényesek azon érdekeltségén, hogy az egyes vállalatok hogyan teljesítenek. Mivel a cégek sarkalatos szerepet töltenek be gazdaságainkban..., a jó corporate governance a népesség széles és egyre növekvő szegmenseinek fontos" (OECD, 2004: 3. o.). 
A corporate governance e ,jóléti hatásának" kiemelése koherenciát mutat a közgazdaságtan (és a jogalkotók) azon tételével, mely szerint a versenykorlátozás a társadalom számára káros. ${ }^{9}$ A versenyszabályozás és a corporate governance kapcsolata ezek alapján nem merül ki a közgazdaság hatékonysági szemléletében, hanem egyfajta etikai kapcsolatot is megtestesít.

Az OECD 2004-es iránymutatása hat alapelvet nevesít a jó corporate governance ismérveként, amelyek az „egészséges” vállalatirányítási módszereket és struktúrákat helyezik a középpontba. Az elsô alapelv a múködô corporate governance alapfeltételeinek megteremtését emeli ki, amely „támogatja a transzparens és hatékony piacokat, összhangban van a jog uralmával, és egyértelmúen kifejezi a különbözó felügyeleti, szabályozó és végrehajtó szervezetek közötti felelősségmegosztást" (OECD, 2004: 17. o.). Az iránymutatás kívánatosnak tartja, hogy a részvényesek gyakorolhassák a közvetlenül a vállalati tulajdonláshoz vagy a vállalatirányításhoz kapcsolódó jogaikat. Mindez azt sugallja, hogy a részvényesek és a menedzserek közötti „eróegyensúly” a gyakorlatban nem áll fenn. ${ }^{10}$ Szintén a részvényesek érdekeit hivatott védeni az az elv, melynek értelmében egyenlő bánásmódban kell részesíteni az összes tulajdonost. Jelentốs versenyjogi kérdésekre világíthat rá a harmadik pont, kimondván, hogy ,az igazgatóság és végrehajtó bizottság tagjait kötelezni kell, hogy felfedjék az igazgatóság előtt, ha ... anyagi érdekük füződik bármely olyan tranzakcióhoz vagy ügyhöz, amely közvetlenül érinti a vállalatot" (20. o.). Az iránymutatás negyedik pontja rámutat a felek együttmúködésének fontosságára. Az ötödik pont kimondja, hogy ,az érintetteknek, beleértve az egyéni munkavállalókat és képviseleti szerveiket is, biztosítani kell annak a lehetôségét, hogy szabadon kommunikálják az illegális és etikátlan magatartással kapcsolatos aggodalmaikat..." anélkül, hogy emiatt sérelmet szenvednének. Szintén a vállalat stabilitását hivatott elősegíteni a rendszeres beszámolási kötelezettség és a transzparencia elve, beleértve a vállalatirányítási magatartási kódex rendelkezéseinek fokozott szem előtt tartását is. Végül, az iránymutatás hatodik elvére úgy is tekinthetünk, mint ami keretet ad a vállalatirányítás egészének. Az OECD rámutat, hogy ,a corporate governance keretrendszerének biztosítania kell a vállalat stratégiai irányítását, az igazgatótanácsnak ellenóriznie kell a menedzsmentet, míg az igazgatótanácsnak a cég és a részvényesek felé kell elszámolnia" (24. o.).

Amint az a felvázolt iránymutatásból is látszik, a corporate governance nemcsak a kívánatos magatartásokat rendszerezó, a különbözó vállalati szereplốk felelősségét meghatározó keretrendszer, hanem alapelve- inek betartása hozzájárul úgy a vállalaton belüli, mint a vállalaton kívüli kontroll kialakításához. Míg elóbbi fókusza a vállalati szereplók közötti kapcsolatokat tartja szem előtt (azon belül is fóleg a tulajdonosok és menedzserek közötti egyensúly fenntartására és a szereplók jogainak biztosítására törekszik), addig a vállalaton kívüli kontrollon az állam (és tágabb értelemben a nyilvánosság) szerepét értjük az etikus vállalatirányításban. ${ }^{11}$

A 2008-ban kibontakozó ingatlanpiaci és pénzügyi válság a közgazdaságtan ezen ágát sem hagyta érintetlenül. Az Egyesült Államokban a válságra adott reakcióként született meg a Dodd-Frank Act, amely a pénzügyi szabályozás kapcsán foglalkozik a vállalatirányítás kérdéseivel is (Bainbridge, 2012; CFTC, 2012). Történhetett mindez annak köszönhetóen is, hogy az OECD háromrészes tanulmányt szentelt annak leírására, hogy a válság hatására a corporate governance-ben milyen gyengeségek kerültek a felszínre (Kirkpatrick, 2009), milyen tanulságokkal szolgál(t) a válság (OECD, 2009), és melyek a legjobb gyakorlatok (OECD, 2010). Kiemelésre érdemes az a gondolat, hogy ,a pénzügyi válság jelentôs mértékben a corporate governance hibáinak és gyengeségeinek tulajdonítható" (Kirkpatrick, 2009: 2. o.). A rendszer gyenge pontjai közül megemlítendố a - fóleg a pénzügyi szolgáltatások piacára jellemző - túlzott kockázatvállalási kedv, a követett bérezési „elvek” okozta sebezhetôség, az egyes vállalatirányítási gyakorlatok, vagy a tốketulajdonosok jogainak gyakorlása (Kirkpatrick, 2009; OECD, 2009). Az OECD-tanulmány ugyanakkor kiemeli, hogy az elvek felülvizsgálata helyett a megvalósításukra kell helyezni a hangsúlyt. Ezt kívánja elősegíteni a legjobb gyakorlatok átvételét támogató OECD- (2010) iránymutatás is.

\section{Összegzés}

Tanulmányunkban az Egyesült Államok antitrösztszabályozásának fejlódését mutattuk be. Megállapítottuk, hogy az ipari forradalom és az amerikai polgárháború utáni gyors gazdasági fejlődés és növekedés addig ismeretlen problémákat vetett fel a kapitalista gazdasági rendszer fejlődésében, mivel ebben a folyamatban ekkor már az Egyesült Államok vitte a prímet, ezekre az elsó válasz is innen érkezett. A Sherman Act-ot (1890) abban az értelemben maradandónak tekintjük, hogy a nyugati világban elsốként korlátozta a monopolerô révén gyakorolható jogokat, viszont a szabályozás még nem volt kiforrott. A Sherman Act-on nyugvó korabeli egyesült államokbeli bírósági gyakorlat vezetett el a törvény 1914-es felülvizsgálatához, melynek eredményeként elfogadásra került a Clayton és a Federal Trade Commission Act. A három törvény együttesen 
jelenti ma is azt a normatív jogszabályi keretet, amely az Egyesült Államok trösztellenes felfogását tükrözi: eszerint a monopolerôvel való visszaélés a szabad verseny szempontjából káros, és ezért tiltott.

$\mathrm{Az}$ amerikai antitröszt-szabályozás maga után vonta az összefonódás-ellenôrzési szabályok fejlődését is. A versenyszabályozás ezen ágában mindazonáltal nem figyelhető meg olyan markáns fejlódés, mint amilyen pályát az antitröszt-szabályozás evolúciója leírt. Összességében ezek a szabályok is a potenciális versenykorlátozó formációk létrejöttét hivatottak megakadályozni.

A tanulmány zárófejezetében a corporate governanceszel foglalkoztunk, míg a trösztellenes szabályozás kijelöli a megengedett vállalati magatartás medrét, a corporate governance elvei hivatottak biztosítani, többek között, a vállalaton belüli etikus magatartást. A versenyszabályok eredményessége szempontjából az etikus magatartás, a jogok és kötelezettségek pontos meghatározása szintén kiemelkedő fontosságú; a kettő együttesen képes ugyanis biztosítani a társadalmilag kívánatos, jogkövető és korrekt üzleti magatartást.

\section{Lábjegyzet}

\footnotetext{
* A tanulmányba átemelt idézetek Mill (1983) és Smith (1959) kivételével a szerző fordításai.
}

${ }^{1}$ Mindazonáltal a XVII-XVIII. század előtt is találhatunk olyan állami (királyi) intézkedéseket, amelyeket esetenként szoros kapcsolatba lehet hozni a monopoleróvel, a trösztösödéssel vagy a piacszabályozással, de ezek tárgyalásától - mivel mai befolyásuk többnyire elhanyagolható - eltekintünk.

${ }^{2}$ Az acél- és olajipar is tipikusan olyan iparágak, amelyekben - a beruházások és a felmerülő költségek nagysága következtében - kiemelkedő szerepet játszanak a méretgazdaságossági megfontolások.

${ }^{3}$ Az állam által alkalmazott, a piaci folyamatokat különbözó megfontolásokból befolyásolni kívánó törekvések az 1950-es évek után - a liberalizáció, a dereguláció, a privatizáció vagy a versenyélénkítés révén - háttérbe szorultak, az Egyesült Államokban a liberalizáció az állami szabályozás lebontására irányult (Valentiny, 2008).

${ }^{4}$ A témában 1. részletesebben: Török, 2001.

${ }^{5}$ A Szövetségi Kereskedelmi Bizottság feladata az USA antitrösztszabályozásának adminisztratív jellegú kiteljesítése volt (Fiorito, 2011), azaz „vizsgálódási és ítélkezési feladatokkal rendelkezett" (Viscusi - Vernon - Harrington, Jr., 2000: 66. o.); a törvény egyúttal megtiltotta a kereskedelemben a tisztességtelen versenyfeltételek gyakorlását (Waldman - Jensen, 2001). Az FTC-vel szembeni legfóbb elvárás tehát a trösztellenes szabályok kikényszerítése volt, így kitöltötte a Sherman Act által nyitva hagyott teret $\mathrm{Az}$ antitröszt-szabályok kikényszerítése azonban nem csak a FTC révén történik, hanem az Igazságügyi Minisztérium Antitröszt Részlegével egyetemben (Antitrust Division of the Justice Department) (Viscusi - Vernon, - Harrington, Jr., 2000, Waldman - Jensen, 2001). Jelen tanulmányban a kikényszerítéssel nem foglalkozunk.
${ }^{6}$ A Clayton Act 7. cikke a részvényszerzés útján történó vállalati irányítás-szerzést tiltotta meg, amennyiben az versenykorlátozó eredménnyel járt. Az ilyen jellegú szabályozásra mint a XX. sz. fordulóján megélénkülő, versenytársak közötti összeolvadási gyakorlatra adott válaszként tekinthetünk (Waldman - Jensen, 2001). ${ }^{7}$ Évente felülvizsgálásra kerülő küszöbértékekrôl 1. FTC 2013a.

${ }^{8}$ A vertikális üzleti tevékenységek esetében a vizsgálat esetleges megindításakor három olyan szempontot vesznek szemügyre, amelyek az elsődleges piachoz kapcsolódnak. Ezek a következók: ha fennáll az az eset, hogy az összefonódás a potenciálisan új piacra lépó vállalat esetében valószínútlenné teszi az elsôdleges piacra történő belépést, anélkül, hogy belépne a másodlagos piacra is; az összefonódás eredményeképpen csökkenne az elsôdleges piacra történó belépés esélye; és harmadsorban, versenyellenes korlátozások merülnének fel az elsődleges piacon. A konglomerátum összefonódások esetében a versenyjogi vizsgálódás általában akkor következik be, ha az jelentôs versenyjogi aggályokat vet fel (Waldman - Jensen, 2001).

${ }^{9}$ A versenykorlátozás szükségességét mindazonáltal nem vethetjük el teljes egészében, hiszen osztjuk azt a schumpeteri felfogást, mely szerint a monopolerô az újítás motorja.

${ }^{10}$ A corporate governance áttekintéseként és a felelősségi kérdésekról l. részletesebben pl. Brennan - Solomon 2008.

${ }^{11}$ Vizsgálódásunkat itt csak a versenyszabályozás és a corporate governance kapcsolatát megtestesítő stratégiai vállalatirányítási döntésekre korlátoztuk.

\section{Felhasznált irodalom}

Adkinson, W.F. - Grimm, K.L. - Bryan, C.N. (2008): Enforcement of Section 2 of the Sherman Act: Theory and Practice. Working Paper, 2008. XI. 3., Washington D.C.: Federal Trade Commission

Amacher, R.C. - Ulbrich, H.H. (1986): Principles of Microeconomics. Third Edition. Cincinatti, Ohio: South-Western Publishing

Aubert, C. (2007): Instruments for Cartel Deterrence, and Conflicts of Interests. in: Ghosal, V. - Stennek, J. (eds.): The Political Economy of Antitrust. Amsterdam: Elsevier: 123-148. o.

Audretsch, D.B. (1985): The Celler Kefauver Act and the deterrent effect. Review of Industrial Organization, 2, 4: 322-338. o.

Bainbridge, S.M. (2012): Corporate Governance after the Financial Crisis. New York: Oxford University Press

Berle, A.A. - Means, G.C. (1991): The Modern Corporation and Private Property. New Brunswick, N.J.: Transaction Publishers

Brennan, N.M. - Solomon, J. (2008): Corporate governance, accountability and mechanisms of accountability: an overview. Accounting, Auditing \& Accountability Journal, 21, 7: 885-906. o.

CFTC (2012): Dodd-Frank Act. U.S. Commodity Futures Trading Commission. Interneten: http://www.cftc.gov/ lawregulation/doddfrankact/index.htm (letöltve: 2013. IX. 23.)

Congress (2013): Sherman, John (1823-1900). Biographical Directory of the United States Congress. Interneten: 
http://bioguide.congress.gov/scripts/biodisplay. pl?index=s000346 (letöltve: 2013. III. 18.)

DoJ (2012): Statutory Provisions and and Guidelines of the Anitrust Division. The United States Department of Justice. Interneten: http://www.justice.gov/atr/public/ divisionmanual/chapter2.pdf (letöltve: 2013. III. 24.).

Fiorito, L. (2011): The influence of American economists on the Clayton and Federal Trade Commission Acts. Quaderni del Dipartimento di economia politica e statistica, Universitá degli Studi di Siena, 2011, n. 623: 1-38. o.

FTC (2013a): Hart-Scott-Rodino Premerger Notification Program. Statement of Basis and Purpose. Federal Trade Commission. Interneten: http://www.ftc.gov/bc/ hsr/sbp.shtm (letöltve: 2013. IV. 3.)

FTC (2013b): Hart-Scott-Rodino Premerger Notification Program. Federal Trade Commission. Interneten: http:// www.ftc.gov/bc/hsr/ (letöltve: 2013. IV. 3.)

Ginsburg, D. H. (2009): Synthetic competition. in: Lévéque, F. - Shelanski, H. (eds.): Antitrust and Regulation in the EU and US. Cheltenham: Edward Elgar

Higgs, R. (2011): The transformation of the American economy. 1865-1914. An essay in interpretation. Auburn, Alabama: Ludwin von Mises Intitute

IP (2013): Hart-Scott-Rodino Antitrust Improvements Act of 1976. Investopedia. Interneten: http://www. investopedia.com/terms/h/hart-scott-rodino-antitrustimprovements-act-of-1976.asp (letöltve: 2013. IV. 3.)

Justitia (2013): Brown Shoe Co., Inc. vs United States - 370 U.S. 294 (1962). US Supreme Court Center. Interneten: http://supreme.justia.com/cases/federal/us/370/294/ case.html (letöltve: 2013. III. 26.)

Kirkpatrick, G. (2009): The Corporate Governance Lessons from the Financial Crisis. OECD. Interneten: http:// www.oecd.org/daf/ca/corporategovernanceprincipl es/42229620.pdf (letöltve: 2013. IX. 24.)

Klotz, T.J. (2008): Monopoly Power: Use, Proof, and Relationship to Anticompetitive effects in Section 2 Cases. Working Paper, 2008. XII. 1., Washington D.C.: Federal Trade Commission

La Porta, R. - Lopez-de-Silanes, F. - Shleifer, A. (1999): Corporate Ownership Around the World. The Journal of Finance, 54/2: 471-517. o.

Mill, J. S. (1983): A Szabadságról. Bukarest: Kriterion Könyvk.

Nagy Cs. I. (2010): A viszonteladási ár rögzítésének megítélése a versenyjogi gyakorlatban: az amerikai szövetségi antitrösztjog legújabb fejleményei, az európai vertikális szabályozási rezsim reformja és a magyar versenyjog perspektívái. Budapest: Gazdasági Versenyhivatal
Neumann, M. (2001): Competition policy. History, Theory and Practice. Cheltenham: Edward Elgar Publishing Limited

OECD (2004): OECD Principles of Corporate Governance Organisation for Economic Co-operation and Development. Interneten: http://www.oecd.org/daf/ca/corporateg overnanceprinciples/31557724.pdf (letölt.: 2013. IX. 20.)

OECD (2009): Corporate Governance and the Financial Crisis: Key Findings and Main Messages. Organisation for Economic Co-operation and Development. Interneten: http://www.oecd.org/daf/ca/corporategover nanceprinciples/43056196.pdf (letöltve: 2013. IX. 24.)

OECD (2010): Corporate Governance and the Financial Crisis - Conclusions and emerging good practices to enhance implementation of the Principles. Organisation for Economic Co-operation and Development. Interneten: http://www.oecd.org/daf/ca/corporategover nanceprinciples/44679170.pdf (letöltve: 2013. IX. 25.)

Ourdocuments (2013): Sherman Anti-Trust Act (1890) Interneten: http://www.ourdocuments.gov/doc.php?flash $=$ true $\&$ doc $=51 \#$ (letöltve: 2013 . III. 18.)

Pelle, A. (2010): AzEurópai Közösség kartellszabályozásának német gyökerei. Doktori disszertáció

Romer, C. D. (2003): Great Depression. Econometrics Laboratory Software Archive, University of Berkeley. Interneten: http://elsa.berkeley.edu/ cromer/great_ depression.pdf (letöltve: 2013. IX. 28.)

Sherman Act (1890): The Sherman Antitrust law. Internet Archive. Interneten: http://archive.org/stream/sherman antitrust $024534 \mathrm{mbp} /$ sherman-antitrust $024534 \mathrm{mbp}$ _djvu. txt (letöltve: 2013. III. 20.)

Smith, A. (1959): A nemzetek gazdagsága: e gazdaság természetének és okainak vizsgálata. Budapest: Akadémiai Kiadó

Török Á. (2001): Piacgazdasági érettség többféleképpen? - Néhány alapfogalom értelmezése és alkalmazása a világgazdaság három nagy régiójában. Közgazdasági Szemle, 48: 707-725. o.

Velentiny, P. (2008): A liberalizálódás foka. Magyar Tudományos Akadémia, Közgazdaság- és Regionális Tudományi Kutatóközpont, Közgazdaság-tudományi Intézet. Interneten: http://econ.core.hu/file/download/ vesz08/10_liberalizalodas.pdf (letöltve: 2013. XI. 22.)

Viscusi, W.K. - Vernon, J.M. - Harrington, Jr., J.E. (2000): Economics of regulation and antitrust. Boston: The MIT Press

Waldman, D.E. - Jensen, E.J. (2001): Industrial Organization. Theory and practice. Second edition, Upper Saddle River: Addison Wesley Longman Inc. 